Светлана С. ШЕАТОВИЋ*

Институт за књижевност и уметност Београд
Оригинални научни рад

Примљен: 11. 03. 2020.

Прихваћен: 15. 07. 2020.

\title{
САВИН ТРАГ У ПОЕЗИЈИ ВАСКА ПОПЕ
}

У раду се анализира лик Светог Саве у песничкој књизи Усправна земља и циклусима песама „Ходочашћа” и „Савин извор”, које обнављају улогу првог српског просветитеља. Васко Попа је песник који је и кроз антологију средњовековне српске књижевности Јутро мислено (2008), постхумно објављене, указао на значај и смисао култа Светог Саве. Траг Светог Саве се посматра у поезији Васка Попе кроз неколико аспеката самосвести модерне српске књижевности у другој половини 20. века према Светом Сави као носиоцу српског идентитета. Други правац анализе иде према алузијама и цитатима везаним за деловање Светог Саве и њиховој интерполацији у модерну поезију Васка Попе. алузија.

Кључне речи: поезија, Свети Сава, интертекстуалност, архитекст, реминисценција,

\section{Живи без година без смрти Окружен својим вуковима „Живот Светога Саве”}

Траг Светог Саве у модерној српској поезији је доживео највиши степен артифицијелности у песничкој књизи Усправна земља и циклусима песама „Ходочашћа” и „Савин извор”. Усправна земља и посебно наведени циклуси обнављају улогу првог српског просветитеља и архиепископа на највишим уметничким и поетичким основама у српској поезији 20. века оживљавајући култ Светог Саве. Осам векова од оснивања архиепископије и у последњим деценијама 20. века су оставили дубок траг на поезију песника послератне генерације; од Васка Попе, Миодрага Павловића до Ивана В. Лалића, Љубомира Симовића и Матије Бећковића. Ипак, Васко Попа је први песник који је и кроз антологију средњовековне српске књижевности Јутро мислено (2008), постхумно објављене, указао на значај и смисао култа Светог Саве. Јутро мислено је настало у време када је Васко Попа радио интензивно на припремама за штампање Србљака почетком седамдесетих година. У том периоду обновом националне свести песници се усмеравају на изворе наци-

\footnotetext{
*svetlana.seatovic@gmail.com
} 
оналне културе, култа Светог Саве који се реконституише као и цео спектар тема, мотива и идеја српске средњовековне књижевности и културе. Трагови културе као сведоци деловања владарске породице Немањића и задужбинарске традиције улазе у песничко ткиво као вишеструки симболи националне културе, самосвести и трајања у модерни песнички израз Васка Попе. Јутро мислено је антологија која је настала почетком седамдесетих година прошлог века и са данашње тачке гледишта она је сасвим компатибилна са упредањем Савиног трага и задужбинарских симбола у песничку збирку Усправна земља Васка Попе.

Траг Светог Саве се посматра у поезији Васка Попе кроз неколико аспеката. Први је усмерен на улогу и самосвест модерне српске књижевности у другој половини 20. века према Светом Сави као носиоцу идентитета. Други правац анализе иде према алузијама и цитатима везаним за деловање Светог Саве и њиховој интерполацији у модерну поезију Васка Попе.

Усправна земљ $a^{1}$ Васка Попе је песничка књига која реактивира слојеве културе и симболе српско-византијске традиције у циклусима „Ходочашћа”, „Савин извор”, „Косово поље”, „Ћеле кула” и „Повратак у Београд”. У Усправној земљи анализом интертекстуалних и интермедијалних мотива и симбола српских средњовековних манастира (Хиландар, Каленић, Жича, Сопоћани, Манасија, Сентандреја), фрескописа (Бели анђео), лика Светог Саве у историјском и духовном контексту и религијских симбола (Богородица Тројеручица у песми „Хиландар”) можемо да видимо основну идеју средњовековне књижевности засноване на принципу „поетског тоталитета”, али и траг и лик Светог Саве као великог пастира и предводника народа.

Збирка Усправна земља је изграђена од пет циклуса симболичких наслова од по седам песама, изузев „Савиног извора” који има 8 песама. На тај начин Васко Попа се спустио до наших најдубљих корена које види у Хиландару, преко циклуса посвећеног култној улози Светог Саве, наше националне пропасти оличене у симболици Косова до Ћеле куле и повратка у Београд, новог српског духовног средишта од тренутка када у њему влада Деспот Стефан Лазаревић. Целокупна збирка је са појединачним циклусима песничко ходочашће кроз византијску и српску средњовековну традицију. У првој песми „Ходочашћа” читамо јасну свест о значају културног памћења (термин Јана Асмана из студије Култура памћењ $a^{2}$ ) и вишеструки смисао ходочашћа као облика homo religiosusa i homo vitora протканог етосом, патосом и логиком одређеног путешествија (термини Карла Маце из студије Поклоничка путовања и феномен верског $)$ : „Ходам са очевим штапом у руци / Са упаљеним срцем на штапу // Стопала ми сричу слова / Која ми свети пут исписује // Цртам их штапом по песку / Пред спавање / На сваком коначишту / Да ми се из сећања не избришу". Традиција српско-византијске културе се модернизује у Усправној земљи и она на тај начин постаје најдубљи Савин траг у симболичком смислу који је синтеза савременог песничког израза и култур-

\footnotetext{
${ }^{1}$ Сви цитати се узимају према издању: Попа 1997.

${ }^{2}$ Видети Асман 2011.

${ }^{3}$ Видети Маца 2009.
} 
ног наслеђа. Такав синтетички израз представља упредање елемената византијског наслеђа (златно и плаво као у песми „Манасија”) или историјског догађаја ослоњеног на Велику сеобу дела српског народа на север када долази до условног прекида са византијском традицијом. Великом сеобом српски народ делимично чува остатке наслеђа средњовековне српске културе који се читају у песми „Сентандреја” где је саграђено „седам сунцомоља”. Контекст Усправне земље у тренутку њеног објављивања 1972. године је од посебног књижевноисторијског значаја. Реконструисање византијске културе и свест о интегративности српске културе са старом књижевношћу почиње у нашем модерном периоду веома интензивно од тренутка када се објављује Србљак. То је кључна књига која је мењала самосвест и самоспознање сопствених корена у најширем кругу српских књижевника (Васко Попа, Иван В. Лалић, Миодраг Павловић, Јован Христић, Матија Бећковић, Милосав Тешић).

Византијска култура и српска средњовековна књижевност од 70-тих година 20. века када се објављује Србљак, зборник средњовековне књижевности, и критике Србљака постају саставни део модерне песничке и националне свести. Уз Србљак у послератној поезији се од 70-тих година формира нови култ Светог Саве, који се афирмише као облик модерног спаситеља, просветитеља и духовног вође. Тако се форматира Савин траг не само у Усnравној земљи већ и широком луку српске поезије и културе. Јутро мислено, антологија српске средњовековне поезије Васка Попе, настаје почетком седме деценије, а остаје скривена у рукопису све до 2008. године, када је приређује, по жељи песника, постхумно Александар Петров. Попина антологија припада истом књижевном периоду у коме се обнавља самосвест песника и културних делатника седамдесетих година. Васко Попа 1972. године објављује Усправну земљу, која реафирмише све домете српске културе, манастира са византијским стилом и култ Светог Саве као зачетника српске књижевности, цркве и школе. На тај начин треба посматрати и Усправну земљу и траг Светог Саве који се ревитализује кроз низ других књижевноисторијских и културолошких делатности. Тек сада, са ове временске дистанце, када знамо и за тајно састављену антологију Јутро мислено и објављену 2008. године, много јасније можемо сагледати улогу и начин на који се форматира Савин траг у модерној култури и поезији. Циклус песама „О делима љубави или Византија” Ивана В. Лалића публикован је 1969. године као циклус у оквиру Изабраних песама, три године пре Попине збирке и тиме је скренута пажња на најновије тенденције и улогу византијске културе као основе српске средњовековне књижевности. Антологија средњовековне књижевности Васка Попе Јутро мислено је посебан аспект који је допринео систематском сагледавању нашег књижевног наслеђа са посебном доминацијом дела Светог Саве. Васко Попа је био изложен ударима режимске критике која је оштро полемисала о објављивању Србљака, који је објавио CКЗ на залагање управо овог песника. Због политичких и друштвених околности ова антологија као важан део Савиног трага у делу Васка Попе није била присутна истраживачима до последње деценије што је донело сасвим јаснију слику о целокупном контексту књижевних и ванкњижевних односа. Васко Попа је најпре 
објављивао циклусе „Косово поље” у Кюижевности 1971, а „Савин извор” у Летопису Матице српске и „Ходочашћа” у Савременику обједињујући их у Усправну земљу 1972. године. На тај начин су ови циклуси прошли проверу актуелне књижевне сцене која је била изузетно активна у периодици и кроз ову поступност песник је стигао до коначног целовитог публиковања збирке Усправна земља. Само на примеру ове поступности која је пратила реакције у књижевној периодици видимо са колико опреза је Васко Попа приступао теми ревитализације средњовековне књижевности у најширем друштвеном контексту. Тактичност у аспектима који нису били књижевни Васка Попу су довели до одлуке да одустане од штампања Јутра мисленог. Ипак, наредних година у Попином опусу ређају се циклуси песама и збирке инспирисани и интертекстуално одређени српском средњовековном историјом, митовима и легендама који се идентификују на семантичком и лексичком плану.

Седамдесете године су обележене друштвеним и политичким променама и новом валоризацијом старих књижевности и религије које су везане за објављивање Србљака. У песми „Хиландар” Попа обнавља средњовековни жанр молитве директним обраћањем Тројеручици, а непосредност коју остварује је резултат модерног песничког гласа уједињеног са тоном понизности византијских и наших песмословаца. Икона Богородице Тројеручице је уточиште уморног ходочасника који је одређен омиљеном иконом у српском народу која је представљала и само веровање у чудесно спасење појединца и национа. Чудесно спасење Јована Дамаскина преточено у икону Богородице Тројеручице представља један од симбола иконописа којем се српски верници најчешће враћају и зато ће Попин ходочасник управо молити пред овом иконом: „Пружи ми три мале нежности / Док ми не падне хиљаду магли на очи / И главу не изгубим // И док теби све три руке не одсеку / Црна мајко Тројеручице”. На крају песме се потврђује структура иконописачког култа Богородице Тројеручице јер се асоцијацијама призивају њена симболичка обележја именована као „три руке” и директним позивањем и асоцијацијом „Црна мајко Тројеручице”. У Усправној земљи Васко Попа отвара стари средњовековни термин ходочашћа као посебног верског и духовног путовања. Због тога није случајно да се збирка и отвара истоименом песмом. Ходочашћа имају и стару средњовековну, али и православно-религијску функцију. Попина намера је била да се крене путевима националног средњовековног ходочашћа, али и путевима, топонимима и симболима који су обележили траг Светог Саве. На ходочашћу Попин јунак путник - Св. Сава, носи штап, песак, прате га вукови симболишући врховног паганског владара који ће се преточити у хришћанску симболику, али и симбол историјског родоначелника самосталне српске православне цркве и брата првог српског краља. Долазак Св. Саве са симболиком паганског периода, штап и вучји траг представља обнову српске културе и спајање старе и нове књижевности, синтезу најдубљих чак и паганских облика веровања код Срба са византијским и најстаријим средњовековним периодом. Потом у циклусу „Ходочашћа” следе песме које представљају културни низ најзнаментијих српских манастира: Хиландар на Светој гори који је и основао Св. Сава, а потом Каленић, најмлађи манастир из 
15. века, који је основан у време Деспотовине када је Србија већ потпала под османску власт. Затим се хронолошки след враћа уназад опет на најрепрезентативније манастире српске средњовековне државе; Жичу, Сопоћане, Манасију, па опет унапред ка Сентандреји, симболу најсеверније тачке до које је стигао српски народ у сеобама крајем 17. и у 18. веку. Овај низ манастира и симбола српске културе указују на самосвест модерних песника и потребу да се споје византијски и стари средњовековни утицаји са модерним добом. У низу песама посвећених Светом Сави као култној личности средњовековне Србије назиремо потребу да се покажу извор, домети и најбоље тековине овог српског писца, племића, првог архиепископа и оснивача првих школа у Србији. После микроциклуса посвећеног Светом Сави Васко Попа уводи мотиве Косова и Косовог поља као симбола страдања српске државе, па ће у песми „Косово поље” казати: „Поље као свако / Длан и по зеленила” и на крају песме: „Поље као ниједно / Над њим небо / Под њим небо”. Тиме се отвара усправни пут духовног страдања и вертикалног, небеског ходочашћа косовских жртава.

Свети Сава је светитељ који је носилац особина некадашњег врховног бога у паганском периоду и приближава се особинама подземног, хтонског света. Лик Светог Саве се повезује ипак са већим бројем соларних мотива који су најближи богу Перуну. Пратећи Савин траг од конститутивног места које се налази у најдубљим слојевима српске религије, Попа уздиже Светог Саву путевима христијанизације. Соларна симболика је у српској култури условљена наслеђем које је одређено историјским, митским, фолклорним, и на крају средњовековном књижевношћу. За конституисање трага Светог Саве најважнији је циклус „Савин извор”, који је облик духовног ходочашћа и уздизања Св. Саве, од одрицања световног живота до уздизања у двоструки лик који досеже до „свевидећег ока”: „Гледа у камену / Своје треће око”. Циклус о Светом Сави, првом српском пастиру, као облик синтетизоване паганске и старе средњовековне културе смештен је у религијско духовни облик ходочашћа. У другој песми „Живот Светог Саве” налазимо укрштаје хришћанског и паганског наслеђа. Најпре је Сава онај који „тимари громове и муње" чиме му Попа даје основне атрибуте вучјег пастира, али као бог Перун чува „златоруне облаке”. У репертоару интертекстуалних алузија на репозиторијум паганских јунака који су уграђени и у фолклорно стваралаштво Свети Сава као пастир има „змијоглави” штап као симбол мудрости и исцељења. У песми „Ходочашћа” Свети Сава креће на пут са „очевим штапом у руци” што је вишеструка алузија на штап Стефана Немање, али и на „очевину” у смислу који је ослоњен на дубље слојеве колективног културног наслеђа. Штап са којим креће на пут је и штап са којим се враћа и којим „сече мрак на четворо”. Тиме Васко Попа у Савином трагу прати стопе наших колективних трагова религије и народних веровања. С друге стране, иста песма садржи и елементе средњовековних житија јер је „душа жедна Бога” као што је то био и млади Растко Немањић, који је напустио Рашку и кренуо „гладан и жедан” у свет да би пронашао и открио себе. 
У песми „Свети Сава” Васко Попа синтетише најзначајније симболе овостраног и оностраног света у мотивима пчела које су према паганским веровањима код Срба биле преносници гласова из света живих у свет мртвих са улогом вука и вучјих симбола. Већ мотив пчеле отвара цео аспект паганског култа који се везује и за култ вука као првог предводника у претхришћанском периоду. У стиховима песме „Свети Сава” читамо слојеве народне културе, фолклорног наслеђа најстаријих лирских песама где ће поред пчела сада бити вишеструки симболи верига као симбола правде, муња и громова који су алузије на врховног бога громовника и симболичког гласа петла који најављује нову зору и ново јутро народног буђења ослоњено на хришћанску симбологију, а све ће то донети пастир Свети Сава: „Око његове главе лете пчеле / И граде му живи златокруг // У риђој му бради / Засутој липовим цветом / Громови с муњама играју жмурке // О врату му вериге висе / И трзају се у гвозденом сну // На рамену петао му пламти / У руци штап премудри пева / Песму укрштених путева // Лево од њега тече време / Десно од њега тече време // Он корача по сувом / У пратњи својих вукова". На крају Сава „корача по сувом” као Мојсије и Христ, али је у пратњи вукова као основног симбола паганског божанства и вучје шапе или шапе звери којом Попа уједињује циклусе и све збирке у макроцелину још од прве збирке Кора. У оваквом синкретизму веровања, симбола и историјских путева са визуелним знацима свих збирки, а посебно Усправне земље која мачем пробија облаке, Попа је песничким и низом интертекстуалних и интермедијалних поступака конструисао дело које је стуб нашег узлазног хода.

Штап који „премудро пева” и „песма укрштених путева” док Свети Сава као маг сече мрак на четворо призивајући улогу Христа који крштењем на све четири стране сједињује опет слојеве културе и религије чини једну од најдубљих културолошких песничких слика у српској поезији. Васко Попа доноси вишеструко симболизовану слику Светог Саве који сече мрак на четворо штапом који је део његовог интегралног бића у песми „Путовање Светог Саве”: „Штапом пред собом / Мрак на четверо сече”. Посебну улогу Светог Саве као оличења самог Христа Попа развија у песми „Свети Сава на своме извору" у којој се сада поред два ока појављује и треће око које представља симболизацију Свевидећег ока Божје силе и Сина Божјег:„Два ока затвара / Трећим оком у камену гледа”. У овој последњој песми циклуса „Савин извор”, који је настао од 1958. до 1971. године, Попа синтетише ход Светог Саве од паганског до хришћанског пастира који се крунише пастирском улогом Христа као звезде водиље која се конституише кроз низове културног и националног памћења. Свети Сава је велики путник homo viagatore i homo religiosus што припада традицији житијне књижевности и фолклорног стваралаштва српског народа. Сава „путује по мрачној земљи” са штапом који пева „песму укрштених путева”. Управо ова синтагма укрштених путева доноси нам бројне историјске и слојевите религијске токове у српској култури. С једне стране, Свети Сава је и као историјска личност био свестан сложености географског положаја средњовековне Србије, која јесте била и остала до данас земља укрштених путева. Ти укрштени путеви су обележили 
и Савине мисије у политичком и верском погледу тражећи подршку са обе стране, и са западне и са источне како би нашао мир, стекао аутокефалност српске цркве и задобио подршку за крунисање брата Стефана Првовенчаног. Штап укрштених путева је и друга врста симболизације коју Васко Попа јасно дефинише у лику Светог Саве, а то је пут укрштања паганског наслеђа и хришћанског начела. Попин траг Светог Саве иде у дубину нашег памћења, спушта се и у хтонске слојеве и уздиже у соларна бића, али га крунише и као протослику Мојсија и Христа. „Штап укрштених путева” је један од најслојевитијих песничких облика који одређује сложеност песничког лика Светог Саве, али и сву комплексност са којом се суочавао у историјском и верском погледу Свети Сава као историјска личност. У штапу укрштених путева је ризница значења која се песнички и историјски ослања на бројне токове које је Васко Попа језичком економијом спрегнутог, а истовремено значењски богатог израза дао поетском лику Светог Саве у Усправној земљи. Попа спушта Светог Саву до најдубљих слојева народног веровања, па он чак и пере шапе својим вуковима. Тиме се развија лук од силаска у хтонски свет, улоге вучјег пастира до христијанизоване слике жреца који штапом „сече мрак на четворо” и преузима улогу Мојсија и Христа. Савин траг само у Попиној поезији можемо пратити овако дубински, а опет се пред нама отвара узлазна линија путника, ходочасника и онога који своју земљу поставља у узлазну вертикалну линију духовног успона. Стога, Усправна земља од вучјих шапа до Трећег, Свевидећег ока земља је која се уздигла путем Светог Саве. Попа је само изузетним познавањем Чајкановићевих збирки, тумачењем, интензивним радом на објављивању Србљака, припремом Јутра мисленог и низом сигурно поузданих тумачења нашег паганског и хришћанског наслеђа могао да синтетизује лик Светог Саве.

Васко Попа је први наш песник који је у послератној поезији и свеукупној књижевности реактивирао лик Светог Саве са свим суштинским обележјима његове мисије у националној историји, култури, просвећености, градећи од њега песнички лик и симбол који је одраз стварне улоге и песничких наноса вишеструке симболизације. У Светом Сави Попа је уградио и модерну перцепцију историјске улоге Растка Немањића као првог архиепископа, оснивача школе и духовног вође. Кроз интеграцију културолошких и религијских етапа у развоју српског народа Попа је у Светом Сави сазидао зиданицу нашег духовног бића кроз векове од симбола липе, пчеле, вукова до штапа који је и пагански и хришћански симбол боготражитеља и пустињака најудаљенијих манастира на ободима Свете Горе, али и у Светој земљи као и у Мојсијевој улози онога који „сухим преко мора” народ изводи из ропства. У лику Светог Саве Попа је уградио и школе и изворе и пастирску улогу у којој га прате вукови, али и симболизацију Христа и Мојсија. Свевидеће, треће око се уграђује у цео хришћански свет над којим бди метафора силе Божије, а у лику Светог Саве и снага националног пастира који бди над својим српским родом. Низом интертекстуалних релација, од алузија до цитата топонима Попа је створио сигурно најдубљи и најсложенији траг Светог Саве у српској култури. Свети Сава је код Попе онај који представља пастира, путово- 
дитеља, мудраца, оног око кога круже пчеле које су пагански симбол бића која прелазе из света мртвих у свет живих, а петао му пева на рамену као облик христијанизације првог који ће казати истину и најавити ново свитање. Због тога Савин траг у Усправној земљи и Попином опусу представља један од најсложенијих облика наше културолошке свести и поезије која је култура памћења утканог у модерне песничке поступке и изразе.

Васко Попа је традицију и историју уградио у сигурно најмодерније песничке изразе, док је Иван В. Лалић тежио интегрисању модерног и традиционалног исказа. Милосав Тешић је отишао најдаље у лексичком и версификацијском погледу наслањајући се и на литерарни ток својих песника претходника и савременика. У том правцу се могу сагледати Тешићеве збирке Прелест севера. Круг рачански, Дунавом и Седмица. Милосав Тешић ће у Прелести севера. Круг рачански, Дунавом (1995) попут Васка Попе из Усправне земље (1972) увести јунака лирског циклуса који је фигура верујућег човека (homo religiosus) и фигура човека путника (homo viator). У књижевноисторијском низу тако можемо видети како се феномен ходочашћа као духовног пута културе сећања у српској поезији обнавља на другачијим поетичким основама кроз само двадесетак година. Усправна земља је остварила утицај на наредне генерације песника који су је продубили и још јаче синтетизовали византијско и старо српско наслеђе, а лик Светог Саве је поставила за сада на најкомплекснији песнички ниво.

\section{ЛИТЕРАТУРА}

Асман 2011: Јан Асман, Култура памћења, Писмо, сећање, и политички идентитет у раним високим културама, превео Никола Б. Цветковић, Просвета, Београд.

Маца 2009: Карло Маца, Поклоничка путовања. Верски туризам, историјско-културолошки приступ, Службени гласник, Београд.

Попа 1997: Васко Попа, Сабране песме, Друштво Вршаи лепа варош, Вршац.

Svetlana S. Šeatović

SAVA'S TRACE IN THE POETRY OF VASKO POPE

Summary

The paper analyzes the character of Saint Sava in the book of poems Uspravna zemlja and the cycles of poems "Hodočašća" and "Savin izvor", which restore the role of the first Serbian educator and archbishop. Eight centuries since the founding of the archbishopric and in the last decades of the 20th century have left a deep mark on the poetry of poets of the post-war generation; from Vasko Pope, Miodrag Pavlović to Ivan V. Lalic, Ljubomir Simovic and Matija Beckovic. Vasko Popa is the first poet who, in the early 1970 s, through the anthology of medieval Serbian literature Jutro misleno (2008) published posthumously, points out the significance and meaning of the cult of Saint Sava. The paper presents an analysis of the character of Saint Sava in these cycles in the context of cultural and social 
changes. The first is focused on the role and self-awareness of modern Serbian literature in the second half of the 20th century towards Saint Sava as the bearer of identity. The second direction of analysis goes towards allusions and quotations related to the actions of Saint Sava and their interpolation into the modern poetry of Vasko Popa. In the Uspravna zemlja, by analyzing intertextual and intermedial motifs and symbols of Serbian medieval monasteries (Hilandar, Kalenić, Žiča, Sopoćani, Manasija, Sentandreja), the figure of Saint Sava in the historical and spiritual context and religious symbols (Bogorodica Trojeručica), we find the basic principles of medieval literature. "Poetic totality", but also the trace and character of Saint Sava as a great shepherd and leader of the people who synthesizes Christian and pagan heritage. Thus, the trace of Saint Sava as a "wolf shepherd" and a Christian saint is synthesized in poetry and anthological selection as an authentic person who is a reflection of our complex cultural matrix. 